\title{
Influences of pulsed light-UV treatment on the storage period of dry-cured meat and shelf life prediction by ASLT method
}

\author{
Na Liu ${ }^{1,2,3}$ - Qiujin Zhu ${ }^{1,2,3} \cdot$ Xuefeng Zeng ${ }^{1,3}$ - Bowen Yang ${ }^{1,3}$ - Meilian Liang ${ }^{1,3}$. \\ Ping $\mathrm{Hu}^{1,3} \cdot{\text { Laping } \mathrm{He}^{1,3}}^{1,}$ Li Deng ${ }^{1,3}$. Cai Liang ${ }^{4}$ Ruping Zhang ${ }^{4}$. \\ Juan Zhou ${ }^{4}$
}

Revised: 8 November 2018/Accepted: 24 January 2019/Published online: 9 March 2019

(C) Association of Food Scientists \& Technologists (India) 2019

\begin{abstract}
In order to prolong the shelf life of Chinese traditional dry-cured meat products, a pulsed ultraviolet light (PL-UV) irradiation method was adopted to treat meat products according to the following parameters: pulse energy of $8 \mathrm{~J}, 300$ pulses, and an effective exposure distance of $10 \mathrm{~cm}$; the UV light irradiation power of $6 \mathrm{~W}$, an effective exposure distance of $11 \mathrm{~cm}$, and an exposure period of $5 \mathrm{~min}$. After a pulsed ultraviolet irradiation, total bacterial count in dry-cured meat decreased from 6.89 to $4.53 \mathrm{lg}$ (CFU/g). The number of Micrococcus and Staphylococcus in samples decreased from 6.49 to $4.10 \mathrm{lg}$ (CFU/g) and the number of molds and yeasts decreased from 5.45 to $4.28 \mathrm{lg}(\mathrm{CFU} / \mathrm{g})$. The number of Lactic acid bacteria increased from 3.97 to $4.55 \mathrm{lg}$ (CFU/g) and Escherichia coli was not detected. Total colonies, target bacteria, peroxide value, thiobarbituric acid-reactive substances, water activity, $T_{2}$ relaxation time, $\mathrm{pH}$, color difference, total volatile basic nitrogen, and the sensory evaluations of dry-cured meat products after PL-UV treatments were determined in a 30-d storage experiment. The shelf life of dry-cured meat treated with PL-UV
\end{abstract}

Qiujin Zhu

1s.qjzhu@gzu.edu.cn

$\triangle$ Xuefeng Zeng

heiniuzxf@163.com

1 School of Liquor and Food Engineering, Guizhou University, Guiyang 550025, China

2 School of Life Science, Guizhou University, Guiyang 550025, China

3 Guizhou Provincial Key Laboratory of Agricultural and Animal Products Storage and Processing, Guiyang 550025, China

4 Guizhou Wufufang Food Co., Ltd., Guiyang 550018, China irradiation at $20{ }^{\circ} \mathrm{C}$ was predicted to reach to $294 \mathrm{~d}$ by applying of shelf life testing method accelerated. The quality and safety of dry-cured meat treated with PL-UV irradiation was better than that of untreated samples.

Keywords Dry-cured meat product · Pulsed light-UV . Antibacterial · Lipid oxidation · Quality

\section{Introduction}

Dry-cured meat is a popular meat product and accounts for a large proportion of processed meat products (Villalobosdelgado et al. 2014). It has different names in various countries, such as pastirma (Turkey, Egypt, and Russia), biltong (South Africa), cured meat (United States), charqui (South America), pemmican (North America), tasajo (Cuba), nikku (Canadian Arctic), cured and smoked pork loin (loin ham) (Japan), cured meat (China), carne seca (Mexico), and fenalår (Norway). Chinese dry-cured meat product is a non-instant meat product made from fresh (frozen) livestock meat and other auxiliary materials by pickling, drying, and smoking. It has obvious advantages, such as simple processing technique, special chewiness and flavor (Zhang and Zhao 2017), convenient storage and transportation, and rich nutrients. However, dry-cured meat products are easily contaminated by bacteria, which may lead to lipid oxidation and protein spoilage in the storage period (Asefa et al. 2010). In general, the spoilage mechanism of meat products is related to biochemical reactions involving internal enzymes and external microorganisms (Ruiz-Capillas et al. 2015; Wu et al. 2016). These spoilage bacteria include gram-negative aerobic bacteria (Pseudomonas, Moraxella, Acetobacter, Aeromonas, Facultative anaerobic Enterobacteriaceae, and Alteromonas 
putrefaciens) and gram-positive bacteria (Staphylococcus aureus and Brochothrix thermosphacta) (Ruiz-Capillas et al. 2015). During the storage of dry-cured meat product, the bacterial community composition is changed and one or more bacterial species become the dominant bacteria and cause the spoilage.

Pulsed light sterilization belongs to non-thermal sterilization technologies based on instantaneous high-intensity wide spectrum pulsed light and has been widely applied in cereals, oil products, livestock products, poultry products, aquatic products, fruits, and vegetable products for its advantages of uniform sterilization, safe operation, and less environmental pollution (Kayalvizhi et al. 2016; Chen et al. 2015). Pulsed light disinfection treatment can realize the faster sterilization and lower residues than other sterilization methods, such as heating or using chemical disinfectants (Aguiló-Aguayo et al. 2013). The pulsed light technology can reduce L. monocytogenes and S. typhimurium on cured meat and sausage surfaces (Ganan et al. 2013). The continuous wave ultraviolet (UV, 200-400, $\mathrm{NM}$ ) and high-intensity pulsed light (PL) technology as non-thermal methods of liquid foods (Koyyalamudi et al. 2011) have been widely applied in many fields. The technology can reduce the microbial contamination of fresh fruits and does not affect the nutritional value (AguilóAguayo et al. 2013; Funes et al. 2013).

The ultraviolet radiation technology is characterized by high efficiency, easy operation and convenient management and has been applied in water treatment, hospital air disinfection, food packaging disinfection, and antibacterial treatment of beverages, fruits, vegetables, meat products, and sea foods. After the irradiation by short-wave ultraviolet radiation, DNAs of microorganisms break and the replication and cell division of DNA are inhibited, thus leading to cell death. These ingredients and nutritional values of fresh fruit juice, wine, cheese, milk, syrup, whey protein and egg could be maintained under the exposure to UV light (Koutchma 2014). Therefore, UV sterilization technology has a certain commercial value and can applied in surface disinfection of fresh agricultural products and liquid products (Lagunas-Solar 2014) as well as the disinfection of air and water (Guan et al. 2015).

Both pulse light and ultraviolet radiation display some characteristics of surface antimicrobial technologies. However, the combination effect of the two technologies was not reported. In this study, the combined sterilization technology of pulsed light and ultraviolet radiation was used to treat Chinese traditional sliced dry-cured meat products and the feasibility of extending the shelf life by the PL-UV irradiation technology was explored.

\section{Materials and methods}

\section{Materials}

Dry-cured meat products were provided by Guizhou Wufufang Food Co., Ltd., China and processed with fresh pork meat, edible salt, wine and other spices. It was accord with the leave the factory of Guizhou Wufufang Food Co., Ltd. standards. Fresh pork meat was salted at $10{ }^{\circ} \mathrm{C}$ for $24 \mathrm{~h}$ and dried at $(52 \pm 2)^{\circ} \mathrm{C}$ for $20 \mathrm{~h}$, followed by smoking and cooling. The dry-cured meat products were sliced into pieces with the size of $50 \mathrm{~mm} \times 50 \mathrm{~mm} \times 3$ $\mathrm{mm}$ and the weight of $10.00-12.00 \mathrm{~g}$. The samples were stored at $25{ }^{\circ} \mathrm{C}$ for the subsequent experiment.

In the experiment, dry-cured meat was divided into 4 groups: untreated group (Control), pulsed light and ultraviolet radiation group (PL-UV radiation), pulsed light radiation group (PL irradiation), and ultraviolet irradiation group (UV irradiation).

\section{PL-UV light device}

Pulsed ultraviolet light treatment device (Changzhou Lannuo Photoelectric Technology Co., Ltd. China) is composed of a power/control module, a processing chamber, a pulsed light xenon lamp and an UV lamp. There are one layer of steel pallet inside the chamber during the experiment, but the layer of steel pallet can be placed in different locations inside the chamber. A length of the PLUV light chamber is $29 \mathrm{~cm}$, the width of the chamber is $26 \mathrm{~cm}$, and the irradiation area is $754 \mathrm{~cm}^{2}$. The parameters of pulsed light tube are provided as follows: a length of $185 \mathrm{~mm}$, a diameter of $8 \mathrm{~mm}$, single pulse energy of $8 \mathrm{~J}$, a pulse intensity of $7.8 \mathrm{~mJ} / \mathrm{m}^{2}$, a pulse frequency of 1 pulse/ $\mathrm{s}$. The parameters of ultraviolet lamp are provided as follows: a tube length of $185 \mathrm{~mm}$, a diameter of $8 \mathrm{~mm}$, lamp power of $6 \mathrm{~W}$, and the effective wavelength of $254 \mathrm{~nm}$. The processing chamber allows the vertical distance range from $2.35 \mathrm{~cm}$ to $17.80 \mathrm{~cm}$, and UV energy ratio of $28.6 \%$.

\section{PL-UV light treatment and storage}

Before the irradiation treatment, the UV light was on for at least 30 min to allow the constant power. There are one layer of steel pallet inside the chamber during the experiment, The dry-cured meat samples were evenly laid on the steel pallet of the PL-UV processing chamber. The single energy of dry-cured meat irradiated by pulsed xenon lamp was $8 \mathrm{~J}$ and the flashing time was $5 \mathrm{~min}$. The power of the ultraviolet xenon lamp was $6 \mathrm{~W}$. Dry-cured meat was $10 \mathrm{~cm}$ away from the pulsed light source. The distance of dry-cured meat away from the ultraviolet light source was 
$11 \mathrm{~cm}$ and irradiation time was $5 \mathrm{~min}$. The vacuum packing meat was stored at $25^{\circ} \mathrm{C}$. The surface bacterial inactivation effect and the quality of dry-cured meat were determined in the subsequent storage period.

\section{DNA extraction, amplification, sequencing and multivariate statistical analysis}

The variable regions of prokaryotic $16 \mathrm{~S}$ rDNA samples were amplified to identify the environmental prokaryotic microbial composition and abundance. The primers can effectively amplify 3 variable regions of $16 \mathrm{~S}$ rDNA (V3, V4, and V5) and accurately identify various species of bacteria including archaea: forward primer $5^{\prime}$ CCTACGGRRBGCASCAGKVRVGAAT- $3^{\prime}$ and reverse primer $5^{\prime}$-GGACTACNVGGGTWTCTAATCC-3' for V3 and V4 regions; forward primer $5^{\prime}$-GTGYCAGCMGCCGCGGTAA- $3^{\prime}$ and reverse primer $5^{\prime}$ CTTGTGCGGKCCCCCGYCAATTC- $3^{\prime}$ for V4 and V5 regions. PCR products were pooled and purified with the DNA Extraction Kit. Finally, the DNA library was constructed and run on the Miseq Illumina (Beijing Tops Biological Technology Co., Ltd, Beijing, China). The OTUs were identified by the partial least square discriminate analysis (PLS-DA) in Simca-P+ software (Version 12.0, Umetrics $\mathrm{AB}$, Umeå, Sweden).

The high-throughput sequencing technology was employed (Fig. 1). The sequence error rate distribution is used to detect whether there is a high error rate in the base sequence. If the sequence error rate is expressed in $e$ and the base mass value of Illumina HiSeqTM/MiSeq is expressed in Qphred, we get the following relationships:

Qphred $=-10 \log 10(e)$

\section{Microbiological quality evaluations}

The quantity of colonies was determined according to China National Food Safety Standard (GB 4789.2-2016): Aerobic Plate Counting, it was incubated 2 days at $37{ }^{\circ} \mathrm{C}$, $25 \mathrm{~g}$ samples were homogenized with $225 \mathrm{~mL}$ Peptone Water Saline (PWS) composed of $0.85 \% \mathrm{NaCl}$; Micrococcus and Staphylococcus (Yantao et al. 2010): MSA medium inverted plate, it was incubated $48 \mathrm{~h}$ at $30{ }^{\circ} \mathrm{C}$; Molds and yeasts were counted according to China National Food Safety Standard (GB 4789.15-2016): PDA medium inverted plate, it was incubated 5 days at $28{ }^{\circ} \mathrm{C}$; Lactic acid bacteria were counted according to China National Food Safety Standard (GB 4789.35-2016): MRS medium inverted plate, it was incubated $72 \mathrm{~h}$ at $37{ }^{\circ} \mathrm{C}$; Escherichia coli were counted according to China National Food Safety Standard (GB 4789.3-2016): VRBA medium inverted plate, it was incubated $24-48 \mathrm{~h}$ at $37^{\circ} \mathrm{C}$. The samples tested in triplicate.

The germicidal effects of various factors on dry-cured meat were analyzed based on the experimental results. The inactivation rate was calculated according to the following formula (Cai et al. 2015).

$Y=\frac{S-S_{0}}{S} \times 100 \%$

where $Y$ is bacterial inactivation rate; $S$ is the total number of colonies of dry-cured meat $(\mathrm{CFU} / \mathrm{g}) ; S_{0}$ is the total number of bacterial colonies in dry-cured meat treated with PL-UV light irradiation (CFU/g).

\section{Peroxidation value and thiobarbituric acid-reactive substances}

Peroxidation value (POV) was measured according to analysis method for determination of peroxide value in foods (GB/T5009.227-2016, China). extracting the fat of dry-cured meat by rotary evaporator (RE-2000A, Ya Rong Biochemical Instrument Factory, China). Each sample was measured 3 times to obtain the average value.. Thiobarbituric acid-reactive substances (TBARS) values were determined according to Bai's thesis (Bai et al. 2008). Take $10 \mathrm{~g}$ of minced dry-cured meat, add $50 \mathrm{~mL}$ of $7.5 \%$ trichloroacetic acid (containing $0.1 \%$ EDTA), shake for $30 \mathrm{~min}$, filter twice with double-layer filter paper, and add $5 \mathrm{~mL}$ of supernatant to $5 \mathrm{~mL}$ of $0.02 \mathrm{~mol} / \mathrm{L}$ TBA. The solution was incubated in a $90{ }^{\circ} \mathrm{C}$ water bath for $40 \mathrm{~min}$, taken out and cooled for $1 \mathrm{~h}$, centrifuged for $5 \mathrm{~min}(1600 \mathrm{r} /$ $\min$ ), and the supernatant was shaken with $5 \mathrm{~mL}$ of chloroform, and the supernatant remained unchanged. The absorbance values were colorimetrically determined at $532 \mathrm{~nm}$ and $600 \mathrm{~nm}$ to calculate the TBARS values:

TBARS $(\mathrm{mg} / 100 \mathrm{~g})=\frac{A 532-A 600}{155} \times \frac{1}{10} \times 72.6 \times 100$

\section{Aw and NMR transverse relaxation time (T2)}

The dry-cured meat samples (5-8 g) were evenly placed on the sample plate of the water activity tester to determine the water activity. The lean part was selected as far as possible for the determination. The Aw of the samples were measured according to the operation procedure of the instrument. Each group was measured three times in parallel. The NMR transverse relaxation properties of samples were measured on the MicrNMR magnetic resonance imaging analyzer PQ001 (Niumag MicroMR, China) (Mortensen et al. 2005). The proton resonance frequency was set as $23 \mathrm{MHz}$ and the measurement temperature was 
$32.0{ }^{\circ} \mathrm{C}$. T2 was measured with CPMG sequences. The parameters were set as follows: $\mathrm{R}$ value (the pulse duration between $90^{\circ}$ and $180^{\circ}$ ) of $150 \mu \mathrm{s}$, repeated sampling times of 8, and repeated interval TR of $1800 \mathrm{~ms}$. Exponentially decaying nuclear magnetic signals were adopted. The sample $(1.0 \mathrm{~g})$ was put into the sample tube with a diameter $12 \mathrm{~mm}$. The tube was sealed to prevent moisture evaporation. Then the sample tube was placed in the nuclear tube in the analyzer. The CPMG sequence was used to detect the transverse relaxation of the samples. The relaxation signal is calculated as:

$M(t)=\sum i P i \exp (-t T 2 i)$

where $P i$ is the signal strength of the $i$ th component; $T 2 i$ is the transverse relaxation time of the $i$ th component in the sample. The total signal size is the sum of the sizes of the signals produced by all the components. The CPMG exponential decay curve was inversed by Multi-Explnv Analysis software. The synthetic iterative algorithm was adopted in the software. Based on the discrete and continuous $T 2$ spectra, corresponding measurement data were obtained.

\section{pH and TVB-N}

The $\mathrm{pH}$ measurements were conducted with a $\mathrm{pH}$ meter (Testo 205, Germany). Each sample was measured 3 times to obtain the average results. The samples $(10 \mathrm{~g})$ were minced and placed in a conical flask and then $100 \mathrm{~mL}$ of distilled water was added. The total volatile basic nitrogen (TVB-N) of samples was determined according to the modified Conway microdiffusion method (Li et al. 2012).

\section{Color difference}

A color difference meter (High-quality Colorimeter NH350, Beijing Western Yuanda Science and Technology Co., Ltd., China) was used to measure color changes of the samples during 30-d storage. The $\mathrm{L}^{*}$ values (black, white), $\mathrm{a}^{*}$ values (red, green), $\mathrm{b}^{*}$ values (yellow, blue) and $\Delta \mathrm{E}$ were recorded in each test.

\section{Sensory quality evaluations}

Through the sensory scoring test, the color, odor and status indicators were obtained (Zhou et al. 2010). The sensory model score (scoring standards of sliced Larou) are shown in Table 1 (Health and Family Planning Commission 2015). In the scoring test, 10 food professionals were employed and they received the model of sensory evaluation related to the descriptive profile of sensory attributes (color, odor, and status of dry-cured meat) before testing.
Each panelist could thoroughly discuss and clarify each attribute to be evaluated. All the tests were carried out at controlled temperature under adequate lighting conditions without noise and odor. Four samples were tested by 10 referees for 6 times in 1 month (Day 5, Day 10, Day 15, Day 20, Day 25, and Day 30).

\section{Shelf life model of dry-cured meat}

According to the principle of accelerated shelf life test (ASLT), the ASLT method on the sensory basis was established by detecting the changes of POV in the storage period and the storage period at $20{ }^{\circ} \mathrm{C}$ (market storage temperature) was deduced. The POV should be no more than $0.5 \mathrm{~g} / 100 \mathrm{~g}$. We accelerated the prediction of shelf life based on ASLT method through the destructive experiment. The $\mathrm{Q}_{10}$ is calculated as:

$Q 10=\frac{\theta s(T)}{\theta s(T+10)}$

where $\theta_{s}(T)$ represents the shelf life when the temperature is $T$, and $\theta_{s}(T+10)$ represents the shelf life when the temperature is $(T+10)$.

Then, the prediction formula for the shelf life of drycured meat is provided as:

$Q_{10}^{\left(\frac{T_{0}-T}{10}\right)}=\frac{\theta s(T)}{\theta s\left(T_{0}\right)}$

where $\theta_{s}(T)$ represents the shelf life of dry-cured meat determined at the temperature is $T ; \theta_{s}\left(T_{0}\right)$ indicates the shelf life of dry-cured meat at $T_{0}$ in the acceleration test.

\section{Data processing}

The analyses of variance (ANOVA) and significance $(P<0.05)$ were performed with SPSS 13.0 software. Origin 8.0 software (Originlab Company) was used for data collection and mapping.

\section{Results and discussion}

\section{Variations in total bacterial count during the storage}

The variation of the total number of colonies in four groups of dry-cured meat products during the 30-d storage is shown in Fig. 2a. The total number of colonies of all the groups displayed an increasing trend during the storage. The value in the untreated group increased from 6.88 to $6.95 \mathrm{lg}(\mathrm{CFU} / \mathrm{g})(P>0.05)$, which was higher than that in the PL-UV irradiation group [4.53 lg $(\mathrm{CFU} / \mathrm{g})]$. Pulsed light irradiation prevented bacterial cells from replication (Koh et al. 2016). The total number of colonies in the PL 
Table 1 Sensory scores of dry-cured meat products

\begin{tabular}{|c|c|c|}
\hline Index & Scoring standard & Score \\
\hline \multirow{3}{*}{$\begin{array}{l}\text { Color and lustre (10 } \\
\text { points) }\end{array}$} & The muscle is the rose red or dark red, the fat is transparent and white; no mucus, no mildew & $8-10$ (excellent) \\
\hline & $\begin{array}{l}\text { The muscle is dark red or brown color, the fat color is transparent milky white; no mucus, no } \\
\text { mildew }\end{array}$ & $\begin{array}{l}\text { 4-7.9 } \\
\text { (commonly) }\end{array}$ \\
\hline & The muscle is dark reddish brown or black, fat is yellow mucus, no mildew; & 0-3.9 (bad) \\
\hline \multirow[t]{3}{*}{ Smell (10 points) } & Cured has a strong flavor, no odor, no rancid flavor & $8-10$ (excellent) \\
\hline & Cured has a good flavor, no odor, no rancid flavor & $\begin{array}{l}\text { 4-7.9 } \\
\text { (commonly) }\end{array}$ \\
\hline & Cured is light, it had a bad smell. & 0-3.9 (bad) \\
\hline \multirow[t]{3}{*}{ State (10 points) } & The tissue is tight and dense, Moderate hardness and without foreign body & $8-10$ (excellent) \\
\hline & The tissue is tight and dense, the section is slightly fractured, and there is no foreign body & $\begin{array}{l}\text { 4-7.9 } \\
\text { (commonly) }\end{array}$ \\
\hline & The tissue is loose and loose and has foreign bodies & $0-3.9$ (bad) \\
\hline
\end{tabular}

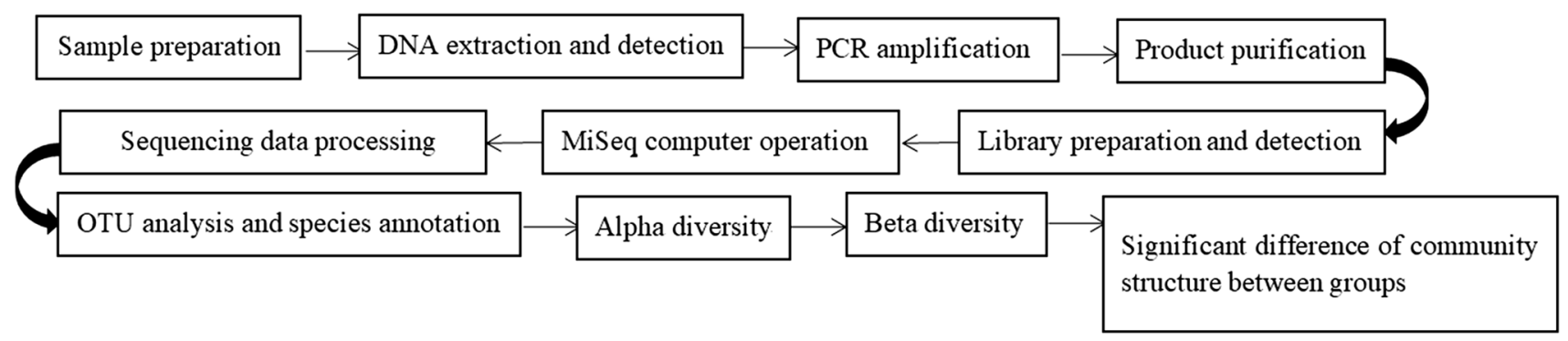

Fig. 1 Sequencing experiment flow

irradiation group increased from 4.95 to $5.96 \mathrm{lg}(\mathrm{CFU} / \mathrm{g})$ $(P<0.05)$ and it increased from 5.15 to $6.31 \mathrm{lg}(\mathrm{CFU} / \mathrm{g})$ in the UV irradiation group $(P<0.05)$. Therefore, the antibacterial effect of PL-UV irradiation group was significant $(P<0.05)$.

The photochemical and photothermal effects of PL-UV irradiation group play a key role in the mechanism of sterilization (Liu et al. 2014). The nucleic acid in microbial cells absorbs a lot of ultraviolet light, forming the isomers of prodiazine and methyldiazine in the condition of PL-UV irradiation. Microbial metabolic dysfunction led to genetic problems and death. Water in cells could be vaporized instantly, thus leading to cell wall breaking and microorganism death within seconds under the condition of photothermal effects, rapid, high-energy, and intense pulsed light radiation. Pulsed light irradiation prevents bacterial cells from replication and division by changing bacterial DNA structure (Koyyalamudi et al. 2011). UV irradiation leads to the death of bacteria by inhibiting DNA replication and cell division. Several reports suggested that at the low light irradiation dose (Hormesis) $\left(\mathrm{B} 1 \mathrm{~J} / \mathrm{cm}^{2}\right)$, the exposure of short-wavelength ultraviolet light $(200-280 \mathrm{~nm})$ for several minutes to $1 \mathrm{~h}$ induced a series of biochemical events in fresh agricultural products, displaying the antimicrobial activity (Ribeiro et al. 2012). In this work, the parameters of PL-UV irradiation were set as follows: pulse energy of $8 \mathrm{~J}, 300$ pulses, ultraviolet lamp power of $6 \mathrm{~W}$, and the effective wavelength of $254 \mathrm{~nm}$. After PLUV irradiation, total bacterial count in dry-cured meat decreased from 6.89 to $4.53 \mathrm{lg}(\mathrm{CFU} / \mathrm{g})(P<0.01)$.

\section{Variations in target bacteria and bacterial phase during the storage}

Through preliminary experiments, we identified the target bacteria in dry-cured meat. The number of Micrococcus and Staphylococcus increased in dry-cured meat during the storage period (Table 2). The number of Micrococcus and Staphylococcus in the Control increased from 6.49 to 6.87 $\lg (\mathrm{CFU} / \mathrm{g})(P>0.05)$. The reduction effects on Micrococcus and Staphylococcus were significant in PL-UV irradiation group $(P<0.01)$. In the PL and UV irradiation groups, the numbers of Micrococcus and Staphylococcus were maintained at about 4-5 $\lg (\mathrm{CFU} / \mathrm{g})$. The numbers of Micrococcus and Staphylococcus in the 4 groups showed the following increasing order: PL-UV irradiation $<$ PL irradiation $<\mathrm{UV}$ irradiation $<$ Control. During the 30-d storage period, the number of Micrococcus or 
Table 2 Target bacteria of dry-cured meat samples during the storage period

\begin{tabular}{|c|c|c|c|c|c|c|c|}
\hline \multirow[t]{2}{*}{ Name } & \multirow{2}{*}{$\begin{array}{l}\text { Dry-cured meat/lg } \\
(\mathrm{CFU} / \mathrm{g})\end{array}$} & \multicolumn{6}{|l|}{ Date (d) } \\
\hline & & $5 \mathrm{~d}$ & $10 \mathrm{~d}$ & $15 \mathrm{~d}$ & 20d & $25 \mathrm{~d}$ & $30 \mathrm{~d}$ \\
\hline \multirow{4}{*}{$\begin{array}{l}\text { Micrococcus and } \\
\text { Staphylococcus } \\
\lg (\mathrm{CFU} / \mathrm{g})\end{array}$} & Untreated group & $6.49 \pm 0.31$ & $6.58 \pm 0.31$ & $6.66 \pm 0.25$ & $6.67 \pm 1.13$ & $6.81 \pm 0.53$ & $6.87 \pm 0.67$ \\
\hline & $\begin{array}{l}\text { PL-UV irradiation } \\
\text { group }\end{array}$ & $4.10 \pm 0.13$ & $4.29 \pm 0.71$ & $4.47 \pm 0.51$ & $4.56 \pm 0.11$ & $4.62 \pm 0.92$ & $4.68 \pm 0.49$ \\
\hline & PL irradiation group & $5.27 \pm 0.51$ & $5.42 \pm 0.36$ & $5.54 \pm 0.91$ & $5.62 \pm 0.42$ & $5.69 \pm 0.71$ & $5.76 \pm 1.56$ \\
\hline & UV irradiation group & $5.31 \pm 0.12$ & $5.46 \pm 0.67$ & $5.52 \pm 0.89$ & $5.65 \pm 0.36$ & $5.75 \pm 0.51$ & $5.80 \pm 0.32$ \\
\hline \multirow[t]{4}{*}{ Molds and yeasts } & Untreated group & $5.45 \pm 0.77$ & $5.56 \pm 0.34$ & $5.64 \pm 0.11$ & $5.71 \pm 1.01$ & $5.76 \pm 0.91$ & $5.80 \pm 0.52$ \\
\hline & $\begin{array}{l}\text { PL-UV irradiation } \\
\text { group }\end{array}$ & $4.28 \pm 0.15$ & $4.34 \pm 0.81$ & $4.47 \pm 1.31$ & $4.57 \pm 0.42$ & $4.66 \pm 0.65$ & $4.71 \pm 0.53$ \\
\hline & PL irradiation group & $4.96 \pm 0.58$ & $5.06 \pm 0.21$ & $5.22 \pm 0.17$ & $5.29 \pm 0.55$ & $5.35 \pm 0.81$ & $5.40 \pm 0.47$ \\
\hline & UV irradiation group & $5.13 \pm 0.31$ & $5.26 \pm 0.58$ & $5.29 \pm 0.11$ & $5.35 \pm 0.25$ & $5.41 \pm 0.59$ & $5.47 \pm 0.81$ \\
\hline \multirow[t]{4}{*}{ Lactic acid bacteria } & Untreated group & $3.97 \pm 0.51$ & $3.85 \pm 0.24$ & $3.71 \pm 0.59$ & $3.33 \pm 0.21$ & $2.96 \pm 0.37$ & $2.76 \pm 0.81$ \\
\hline & $\begin{array}{l}\text { PL-UV irradiation } \\
\text { group }\end{array}$ & $4.55 \pm 0.11$ & $4.31 \pm 0.27$ & $3.98 \pm 0.91$ & $3.84 \pm 0.57$ & $3.69 \pm 0.36$ & $3.47 \pm 0.25$ \\
\hline & PL irradiation group & $4.06 \pm 0.34$ & $3.93 \pm 0.11$ & $3.82 \pm 0.12$ & $3.66 \pm 0.27$ & $3.41 \pm 0.31$ & $3.07 \pm 0.39$ \\
\hline & UV irradiation group & $4.28 \pm 0.13$ & $4.02 \pm 0.24$ & $3.86 \pm 0.07$ & $3.76 \pm 0.11$ & $3.58 \pm 0.37$ & $3.27 \pm 0.21$ \\
\hline \multirow[t]{4}{*}{ Escherichia coli } & Untreated group & 0 & 0 & 0 & 0 & 0 & 0 \\
\hline & $\begin{array}{l}\text { PL-UV irradiation } \\
\text { group }\end{array}$ & 0 & 0 & 0 & 0 & 0 & 0 \\
\hline & PL irradiation group & 0 & 0 & 0 & 0 & 0 & 0 \\
\hline & UV irradiation group & 0 & 0 & 0 & 0 & 0 & 0 \\
\hline
\end{tabular}

Staphylococcus showed no significant change. Lara et al. (2003) studied charqui (a traditional dry-cured beef in Brazil) and found that the number of Staphylococcus in beef decreased sharply after the sunlight exposure. Molina studied microbial changes during the processing process of dry-cured ham in rural areas, found that Micrococcaceae was the dominant bacteria in the pickling and ripening stages, and isolated 600 bacterial strains from the two stages, in which $99 \%$ Micrococcus existed and $90 \%$ of the Micrococcus was staphylococci. The numbers of molds and yeasts gradually increased during the storage period and the numbers of molds and yeasts in the PL-UV irradiation group were the smallest. The numbers of the molds and yeasts in the untreated meat group were the highest. Lactic acid bacteria decreased gradually $(P<0.05)$ along with the increase in $\mathrm{pH}$ and the decline in Aw in dry-cured meat. However, Micrococcus and Staphylococcus became the dominant bacteria and the order of magnitude was still between $5 \mathrm{lg}(\mathrm{CFU} / \mathrm{g})$ and $6 \mathrm{lg}$ (CFU/g). Escherichia coli was not detected in 4 groups of dry-cured meat within 30-d storage (Fig. 2b). In addition, the irradiation treatment could kill $E$. coli under suitable pulsed light intensity (Chen et al. 2009). This study confirmed the significant bactericidal effect of PL-UV irradiation.

\section{Variations in water activity and moisture distribution during the storage}

The water activity reflects the content of free water. During the 30-d storage period, the water activity of 4 groups of dry-cured meat products increased in the following order (Fig. 2c): PL-UV irradiation $<$ PL irradiation $<\mathrm{UV}$ irradiation $<$ Control. The combined effects of pulsed light and ultraviolet radiation were more significant in reducing the water activity than those of single irradiation due to the radiation heat effect of PL-UV treatment (Taghvaei et al. 2015). The relationship between the inactivation rates and the water activities of dry-cured meat is shown in Fig. 3a. The linear relationship was negative $(r=-0.9963$, $P<0.0001)$. PL-UV irradiation treatment led to the higher inactivation rate and the lower water activity in dry-cured meat. The correlation between the inactivation rate and the water activity was significant and the water activity could be used as an index to evaluate the shelf life of dry-cured meat. The shelf life was correlated to the water activity. The lower the water activity was, the longer the shelf life was (Bovercid et al. 2012).

During the storage period, the water activity of the 4 groups of dry-cured meat showed an increasing trend (Fig. 3b) due to the gradual increase in the content of free water. According to the changing trend of the water 


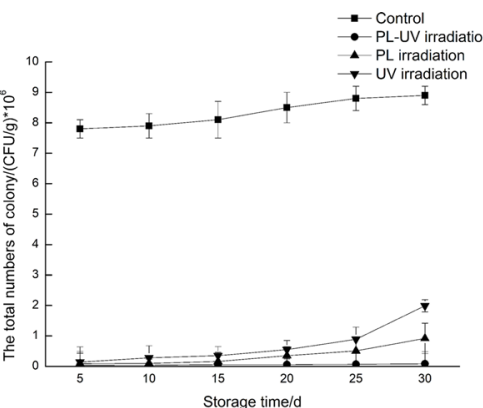

(a)

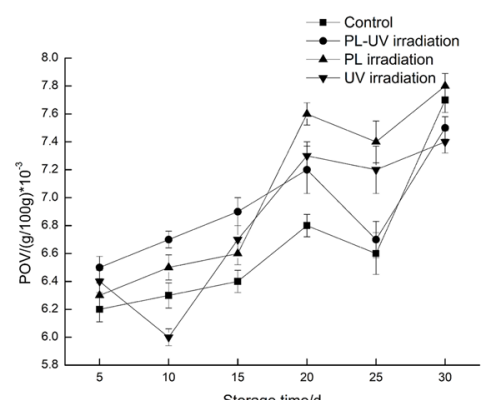

(d)

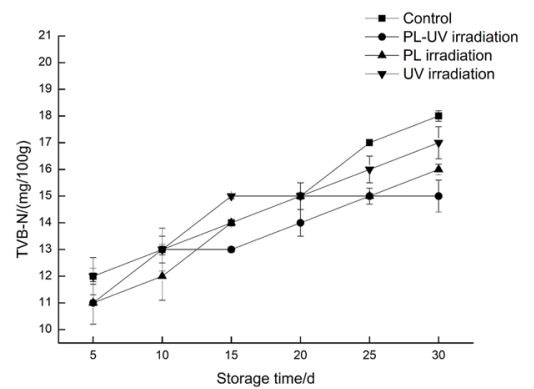

(g)

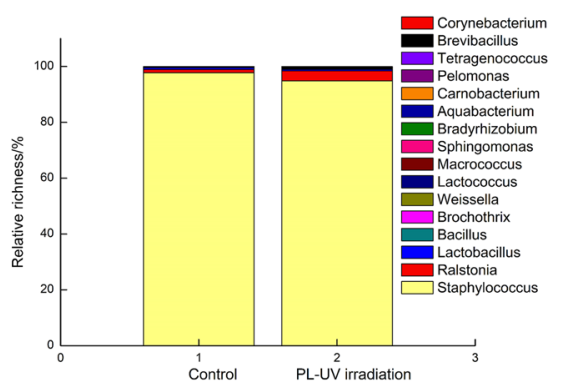

(b)

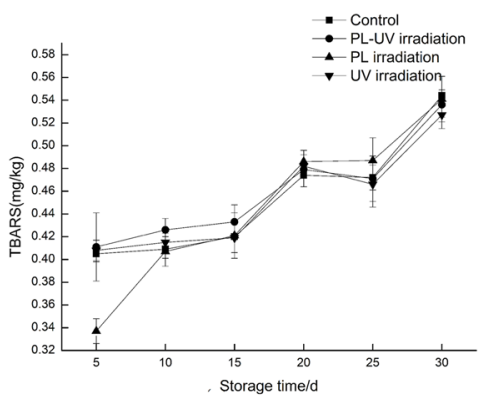

(e)

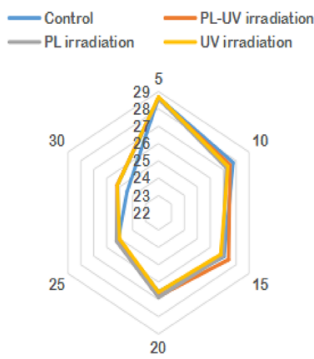

(h)

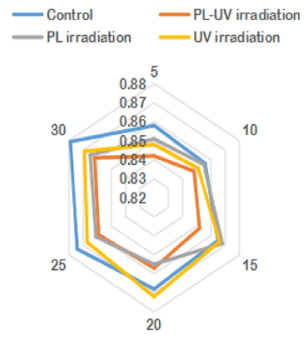

(c)

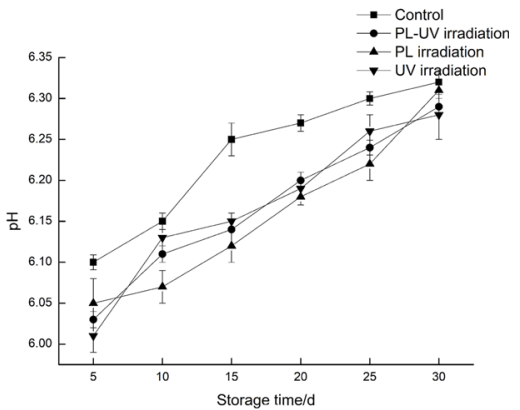

(f)

Fig. 2 Change of quality index of preserved dry-cured meat during storage

activity, 2 groups of cured meat samples were selected as the representative samples (PL-UV irradiation and Control group). Dry-cured meat treated with pulsed light and ultraviolet light showed the decreased peak area, indicating that the water movement was enhanced after PL-UV irradiation treatment. The proportion of each component calculated with the peak area indicated that after the pulse light UV treatment, the proportions of T20 (0.1-1 ms) and $T 23$ (100-1000 ms) were respectively decreased by $2.0 \%$ and $7.5 \%(P<0.01)$ and that the proportions of $T 21$ (1-10 ms) and T22 (10-100 ms) were respectively increased by $2.8 \%$ and $7.4 \% \quad(P<0.01)$. The above changes indicated that the treatment with PL-UV irradiation changed the water distribution in dry-cured meat. The increase in bound water and the decrease in free water are significant, thus contributing the inactivation rate in the end (Colzato et al. 2011). The data indicated that the treatment of PL-UV irradiation changed the moisture distribution (increased bound water and decreased free water) in dry- cured meat and eventually led to an extended shelf life by increasing the inactivation rate.

\section{Variations in POV and TBARS during the storage}

The peroxide value is an index reflecting the degree of lipid oxidation. Higher peroxide values indicate that the more intermediate products of lipid oxidation are accumulated, but these intermediates under oxidation conditions form small molecules. During the 30-d storage, the peroxide values of 4 groups of dry-cured meat showed an increasing trend (Fig. 2d). The peroxide value of the Control group increased from $(0.062 \pm 0.001) \quad \mathrm{g} / 100 \mathrm{~g}$ to $(0.077 \pm 0.001) \mathrm{g} / 100 \mathrm{~g}(P>0.05)$ and the peroxide value of PL-UV irradiation group increased from $(0.064 \pm 0.001) \quad \mathrm{g} / 100 \mathrm{~g}$ to $(0.079 \pm 0.001) \mathrm{g} / 100 \mathrm{~g}$ $(P>0.05)$. The peroxide value increased firstly, then decreased, and finally increased. The strong pulsed light irradiation increased the peroxide value too. Due to a 


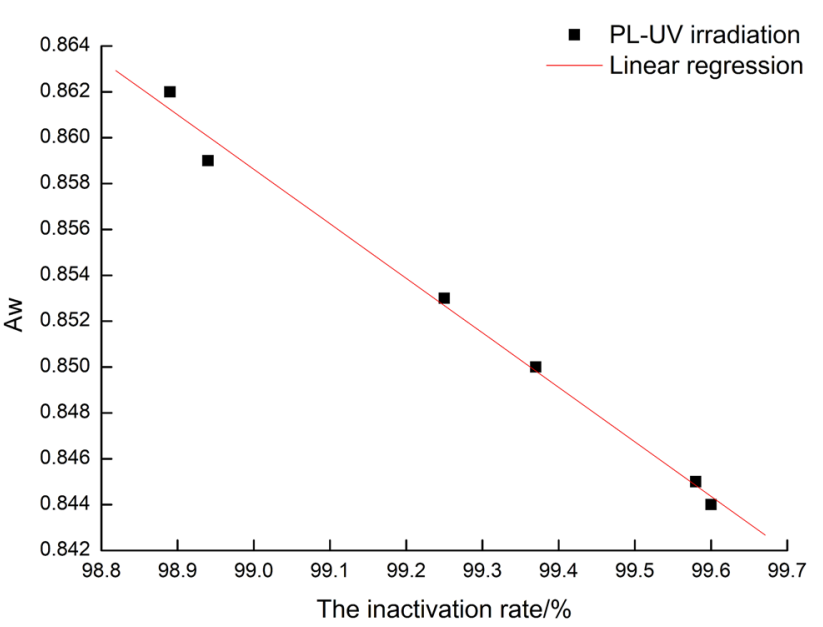

(a)

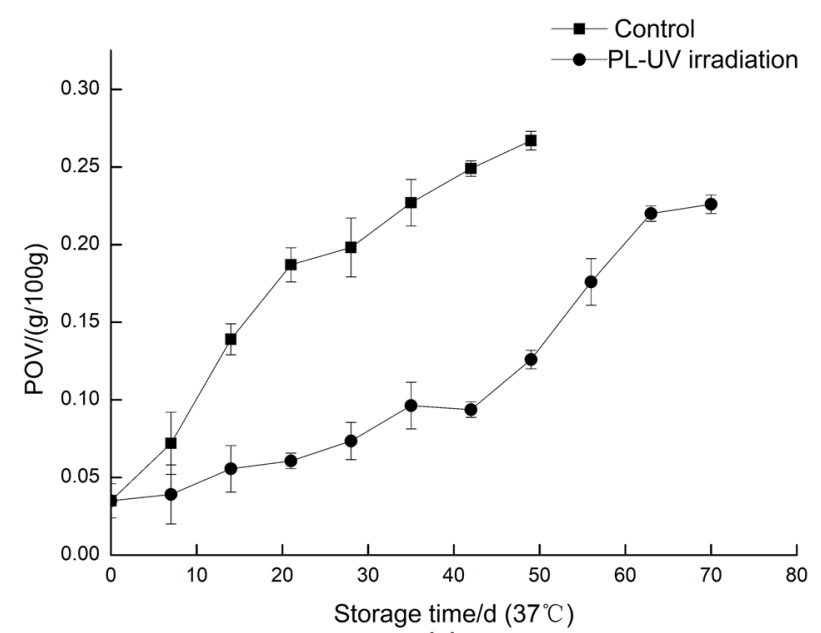

(c)

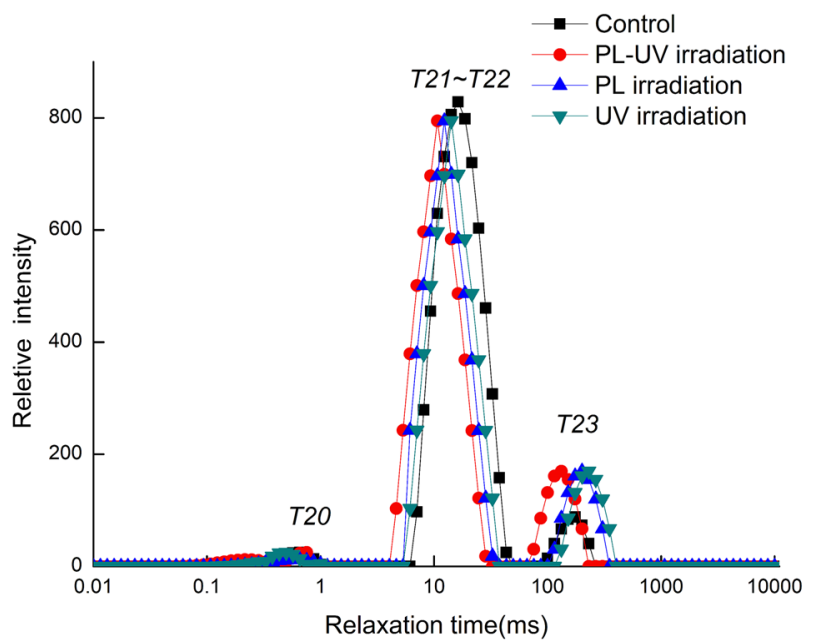

(b)

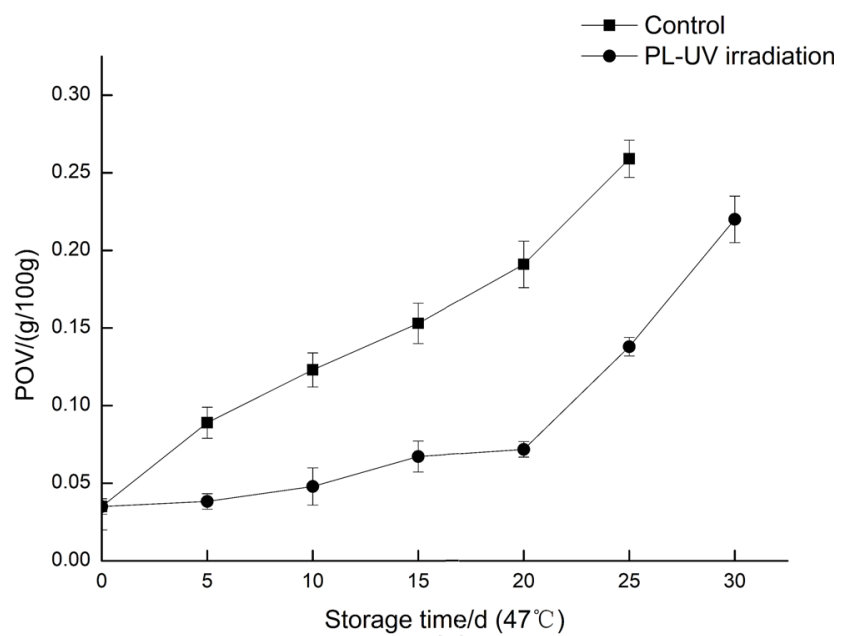

(d)

Fig. 3 Correlation between the bacterial inactivation rate and Aw, T2 Relaxation characteristics after transverse magnetization decay signal inversion, Changes of the POV value of cured meat during storage $\left(37^{\circ} \mathrm{C}\right.$ and $\left.47^{\circ} \mathrm{C}\right)$

stable control of the radiation coefficient of PL irradiation, the peroxide value finally reached $(0.075 \pm 0.001)$ $\mathrm{g} / 100 \mathrm{~g}$. The peroxide value of PL-UV irradiation showed no significant difference compared to that of UV irradiation group $(P>0.05)$. The peroxide values in both groups were lower than that in the Control because the reasonable PLUV irradiation reduced the peroxide value of lipid oxidization meat or stable meat products (Guizani et al. 2014). According to the method for determination of peroxide value in foods (GB/T5009.227-2016, China) of dry-cured meat, the peroxide value shall not exceed $0.5 \mathrm{~g} / 100 \mathrm{~g}$. After dry-cured meat was treated by vacuum packaging, the oxidation products significantly decreased and the shelf life of the product was extended, as indicated by Berdagué et al. (1993). Lipid peroxides are the main lipid oxidation products, which are usually unstable and may be rapidly decomposed or further oxidized into volatiles such as malondialdehyde and ketones (Jerkovic et al. 2007). The
TBARS values of 4 different groups are shown in Fig. 2e. TBARS values can reflect the final lipid oxidation degree because malondialdehyde is one of the ultimate products of lipid oxidation. TBARS can be concluded that some hydroperoxides degraded into thiobarbituric acid reactive substances in this stage (Huang et al. 2014). Malondialdehyde as a derivative of oxidative degradation of unsaturated fatty acids in oils and fats, can react with TBA to form stable red compounds. The higher the TBARS value, the higher the oxidation degree of fats (Pignoli et al. 2009). The TBARS value gradually increased during the storage period, indicating that the peroxides were gradually decomposed to form malondialdehyde, ketones, and other substances. The TBARS values of the 4 groups of drycured meat products increased since Day 15 and became stable at $0.54 \mathrm{mg} / \mathrm{kg}$ on Day 30 . In the final stage, the TBARS tended to be stable due to the degradation or reactions related to malondialdehyde. Malondialdehyde or 
Table 3 Variations of color difference of dry-cured meat during the storage period

\begin{tabular}{|c|c|c|c|c|c|c|c|}
\hline \multirow[t]{2}{*}{ Dry-cured meat } & \multirow[t]{2}{*}{ Index } & \multicolumn{6}{|l|}{ Days } \\
\hline & & $5 \mathrm{~d}$ & $10 \mathrm{~d}$ & $15 \mathrm{~d}$ & $20 d$ & $25 \mathrm{~d}$ & $30 d$ \\
\hline \multirow[t]{3}{*}{ Control } & $\mathrm{L}^{*}$ & $45.12 \pm 0.37^{\mathrm{a}}$ & $45.6 \pm 0.13^{\mathrm{a}}$ & $45.34 \pm 0.44^{\mathrm{a}}$ & $44.42 \pm 0.25^{\mathrm{a}}$ & $44.01 \pm 0.27^{\mathrm{a}}$ & $43.51 \pm 0.21^{\mathrm{b}}$ \\
\hline & $a^{*}$ & $6.80 \pm 0.55^{\mathrm{a}}$ & $7.63 \pm 0.35^{\mathrm{b}}$ & $7.69 \pm 0.62^{\mathrm{b}}$ & $8.11 \pm 0.37^{\mathrm{bc}}$ & $8.38 \pm 0.54^{\mathrm{c}}$ & $7.93 \pm 0.51^{\mathrm{b}}$ \\
\hline & $b^{*}$ & $3.71 \pm 0.06^{\mathrm{a}}$ & $7.11 \pm 0.16^{\mathrm{c}}$ & $7.89 \pm 0.11^{\mathrm{c}}$ & $8.02 \pm 0.08^{\mathrm{d}}$ & $7.04 \pm 0.13^{\mathrm{bc}}$ & $6.65 \pm 0.17^{\mathrm{b}}$ \\
\hline \multirow[t]{4}{*}{ PL-UV irradiation } & $\mathrm{L}^{*}$ & $45.43 \pm 0.17^{\mathrm{a}}$ & $45.71 \pm 0.41^{\mathrm{a}}$ & $45.93 \pm 0.34^{\mathrm{a}}$ & $44.42 \pm 0.39^{\mathrm{b}}$ & $44.01 \pm 0.15^{\mathrm{b}}$ & $43.51 \pm 0.26^{\mathrm{c}}$ \\
\hline & $a^{*}$ & $7.80 \pm 0.55^{\mathrm{a}}$ & $7.63 \pm 0.61^{\mathrm{a}}$ & $7.52 \pm 0.25^{\mathrm{b}}$ & $7.51 \pm 0.39^{\mathrm{b}}$ & $7.72 \pm 0.43^{\mathrm{bc}}$ & $7.88 \pm 0.57^{\mathrm{bc}}$ \\
\hline & $b^{*}$ & $6.85 \pm 0.09^{\mathrm{a}}$ & $7.11 \pm 0.21^{\mathrm{b}}$ & $8.32 \pm 0.03^{\mathrm{c}}$ & $8.12 \pm 0.09^{c}$ & $7.55 \pm 0.10^{\mathrm{bc}}$ & $6.92 \pm 0.04^{\mathrm{a}}$ \\
\hline & $\Delta \mathrm{E}$ & 3.31 & 0.11 & 0.75 & 0.61 & 0.83 & 0.27 \\
\hline \multirow[t]{4}{*}{ PL irradiation } & $\mathrm{L}^{*}$ & $46.67 \pm 0.33^{\mathrm{a}}$ & $45.66 \pm 0.12^{\mathrm{a}}$ & $45.91 \pm 0.14^{\mathrm{ab}}$ & $43.34 \pm 0.19^{\mathrm{b}}$ & $43.45 \pm 0.25^{\mathrm{b}}$ & $43.59 \pm 0.39^{\mathrm{b}}$ \\
\hline & $a^{*}$ & $8.65 \pm 0.15^{\mathrm{a}}$ & $8.97 \pm 0.36^{\mathrm{a}}$ & $9.31 \pm 0.44^{\mathrm{bc}}$ & $8.72 \pm 0.51^{\mathrm{ab}}$ & $9.11 \pm 0.27^{\mathrm{b}}$ & $11.58 \pm 0.62^{\mathrm{c}}$ \\
\hline & $b^{*}$ & $6.38 \pm 0.06^{\mathrm{a}}$ & $6.92 \pm 0.02^{\mathrm{a}}$ & $7.23 \pm 0.14^{\mathrm{b}}$ & $7.50 \pm 0.18^{\mathrm{b}}$ & $8.25 \pm 0.21^{\mathrm{c}}$ & $9.48 \pm 0.13^{\mathrm{d}}$ \\
\hline & $\Delta \mathrm{E}$ & 3.60 & 1.35 & 1.84 & 1.34 & 1.52 & 4.62 \\
\hline \multirow[t]{4}{*}{ UV irradiation } & $\mathrm{L}^{*}$ & $44.26 \pm 0.27^{\mathrm{a}}$ & $44.53 \pm 0.32^{\mathrm{a}}$ & $42.86 \pm 0.39^{\mathrm{ab}}$ & $43.66 \pm 0.17^{\mathrm{b}}$ & $43.13 \pm 0.24^{\mathrm{b}}$ & $42.36 \pm 0.35^{\mathrm{c}}$ \\
\hline & $a^{*}$ & $3.88 \pm 0.33^{\mathrm{a}}$ & $4.57 \pm 0.52^{\mathrm{b}}$ & $5.94 \pm 0.59^{c}$ & $6.31 \pm 0.25^{\mathrm{d}}$ & $6.78 \pm 0.36^{\mathrm{d}}$ & $7.31 \pm 0.39^{\mathrm{e}}$ \\
\hline & $\mathrm{b}^{*}$ & $5.06 \pm 0.02^{\mathrm{a}}$ & $5.28 \pm 0.04^{\mathrm{a}}$ & $5.30 \pm 0.06^{\mathrm{a}}$ & $5.49 \pm 0.03^{\mathrm{ab}}$ & $6.91 \pm 0.15^{\mathrm{b}}$ & $7.98 \pm 0.11^{\mathrm{c}}$ \\
\hline & $\Delta \mathrm{E}$ & 3.33 & 3.72 & 3.99 & 3.20 & 1.83 & 1.86 \\
\hline
\end{tabular}

Control is a standard, All values are mean \pm standard deviation of three replicates $(n=9)$

${ }^{\mathrm{a}-\mathrm{d}}$ Means within a row with different letters are significantly different $(P<0.05)$

their products as well as other compounds, such as amino acids and intermediates of Maillard reaction, endowed drycured meat with a special flavor (Prados et al. 2016).

\section{Variations in color difference during the storage}

The brightness values of 4 groups of dry-cured meat samples tended to decrease gradually and the color and freshness of dry-cured meat gradually decreased during the storage period (Table 3). The $b^{*}$ value (yellowness) was related to the oxidation process of fat. The $b^{*}$ (yellowness) of 4 groups of dry-cured meat samples increased gradually. In dry-cured meat treated with the light irradiation, This result and consistent the Kim's research that the a* (redness) increased to black and $b^{*}$ gradually increased (Kim et al. 2013). The $a^{*}$ increased gradually, indicating the improvement in the color quality. The $\mathrm{L}^{*}$ (brightness) increased and the $b^{*}$ decreased, indicating that the color quality of dry-cured meat declined. The $b^{*}$ value can also reflect the oxidation degree of dry-cured meat, and the higher the $b^{*}$ value is, the higher the degree of oxidation is. The $b^{*}$ value in the PL-UV irradiation firstly increased, then decreased, and then increased and the peroxide value and the TBARS value also showed the same changing trend. As indicated by the changes of $\mathrm{L}^{*}, \mathrm{a}^{*}$, and $\mathrm{b}^{*}$, the quality of the 4 groups of dry-cured meat samples decreased in the following order: UV irradiation $>$ PL-UV irradiation $>$ Control group $>$ PL irradiation. The irradiation increased the $b^{*}$ value. The color changes of dry-cured meat were mainly caused by the decrease in surface water content and oxidation reactions of hemoglobin during the storage period. In the oxidation process of hemoglobin, nitrosylmyoglobin in dry-cured meat was induced by lactic acid bacteria to produce catalase and peroxidase. Wambura and Verghese (2011) indicated that UV irradiation promoted lipid acceleration and that pigments in dry-cured meat were oxidized. $\Delta \mathrm{E}$ is defined as the total color difference of the sample, the larger the value of $\Delta \mathrm{E}$, the color difference is more. Control is a standard, The color difference of the 3 groups of dry-cured meat samples increased in the following order: PL-UV irradiation $<$ PL irradiation $<$ UV irradiation. PL-UV irradiation had a certain effect on $\mathrm{L}^{*}, \mathrm{a}^{*}, \mathrm{~b}^{*}$ and $\Delta \mathrm{E}$ values $(P>0.05)$.

\section{Variations in $\mathrm{pH}$ during the storage}

$\mathrm{pH}$ value is an important indicator of microbial spoilage in meat and meat products and affects the bacterial reproduction, color and water activity of meat products in the storage process (Yano et al. 1995). During the 30-d storage, the $\mathrm{pH}$ values of 4 groups of dry-cured meat samples showed an upward trend because meat proteins were decomposed into alkaline ammonia and amine compounds such as organic bases, which contributed to the reproduction of bacteria (Fig. 2f). The $\mathrm{pH}$ values of the PL-UV 
irradiation and Control after 5-d storage were $6.03 \pm 0.005$ and $6.10 \pm 0.01$, respectively. The $\mathrm{pH}$ values in the samples gradually became the alkaline value. During the storage period, ammonia and amine compounds in drycured meat gradually increased and the $\mathrm{pH}$ values of drycured meat samples gradually rose. However, the $\mathrm{pH}$ value of dry-cured meat sample treated by PL-UV irradiation was lower than that in the Control because irradiation inhibited the alkaline tendency.

\section{Variations in TVB-N during the storage}

TVB-N value, as the main hygienic index, indicates the freshness of meat products and reflects the spoilage degree of meat products (Rodtong et al. 2005). Protein degradation due to enzymes and microorganisms generates alkaline ammonia, amines and nitrogen-containing substances, such as volatile basic nitrogen compounds, which are small molecular substances and toxic non-protein nitrogen-containing compounds, such as metabolism products of amino acids and nucleotides. After 30-d storage, the TVB-N values of the Control, PL-UV irradiation, PL irradiation, and UV irradiation groups were respectively $(18.9 \pm 0.2)$ $\mathrm{mg} / 100 \mathrm{~g},(15.2 \pm 0.6) \mathrm{mg} / 100 \mathrm{~g},(16.1 \pm 0.3) \mathrm{mg} / 100 \mathrm{~g}$, and $(17.5 \pm 0.6) \mathrm{mg} / 100 \mathrm{~g}$ (Fig. $2 \mathrm{~g}$ ). The PL-UV irradiation could guarantee the stability of meat proteins because untreated dry-cured meat was more easily affected by microorganisms, moisture and other factors, thus resulting in the protein decomposition and the production of ammonia and amines. Intense pulsed light and UV irradiation lead to the decomposition of proteins and destroy protein integrity and muscle cell structure (Chen et al. 2009). The broken organelles released a large number of internal enzymes, which further accelerated protein degradation and the release process of the metabolism products of amino acids and nucleotides (Yang et al. 2017; Leygonie et al. 2012).

\section{Variations in the sensory score during the storage}

During the storage period, the sensory score of Control decreased rapidly and the sensory score of PL-UV irradiation was relatively stable because PL-UV irradiation treatment had little effect on the sensory score of the drycured meat samples (Fig. 2h). In the initial storage phase $(0-10 \mathrm{~d})$, the sensory score of untreated group was decreased by 0.25 , but the decrease was not significant $(P>0.05)$. After 5 -d storage, the sensory scores of 3 groups of samples were higher than that of the Control group. After 30-d storage, the sensory score of PL-UV irradiation group was 0.77 higher than that of Control $(P<0.05)$. The dry-cured meat products processed by PLUV irradiation showed a certain flavor. The flavor of meat products mainly came from lipid oxidation (Berdagué et al. 1993). Therefore, pulsed light or ultraviolet irradiation did not significantly change the sensory properties in dry-cured meat during the storage period and PL-UV irradiation could improve the flavor.

\section{Pearson correlation coefficients}

Pearson correlation coefficients between the sensory scores of dry-cured meat and physical and chemical indicators are provided in Table 4. Most of the correlation coefficients were greater than 0.9 , indicating that the sensory index of dry-cured meat had the good correlation with physical and chemical indicators. The sensory score had a significant negative correlation with the total number of colonies, Aw, POV, TBARS, $\mathrm{a}^{*}, \mathrm{~b}^{*}, \mathrm{~T} 21, \mathrm{~T} 22, \mathrm{pH}$, and TVB-N $(* P<0.05 ; * * P<0.01)$ and a significant positive correlation with $\mathrm{L}^{*}$ and $\mathrm{T} 21$. The deterioration of dry-cured meat might be ascribed to microbial growth and fat oxidation during the prolonged shelf life. Fat oxidation barrier affected the growth of microorganisms. Therefore, the correlation coefficient between the total number of colonies and sensory score was less than that between the POV value and the sensory score. Fat oxidation was intensified and lipids were hydrolyzed to form free fatty acids, which were then oxidized into hydroperoxides and eventually decomposed into small molecules such as aldehydes and ketones (Pignoli et al. 2009), thus resulting in a high correlation between POV and TBARS values. Fat oxidation, microbial growth and other factors made the sensory score drop. The required physicochemical indices in Chinese Dry-Cured Meat Standard only include POV value and the correlation coefficient between POV value and the sensory score was the largest in this study, Therefore, the POV value could more precisely reflect the changes in the sensory quality of the dry-cured meat.

\section{Prediction of the shelf life of dry-cured meat by ASLT method}

Finally, the POV value was chosen as the key factor for predicting the quality change and shelf life of dry-cured meat during storage and the ASLT method was built as follows. The $Q_{10}$ can be calculated with the acceleration test results in Fig. 3c, d. The reasons for the peroxidation value of dry-cured meat after PL-UV irradiation are less than the Control: First, the quality of the two types of bacon may be different; Secondly, it is related to the smaller parameters selected by the PL-UV instrument; Thirdly, It may be related to the influence of the total number of colonies on the peroxide value. The total number of colonies of Control is larger than that of the PL-UV irradiation group, which makes the Control 


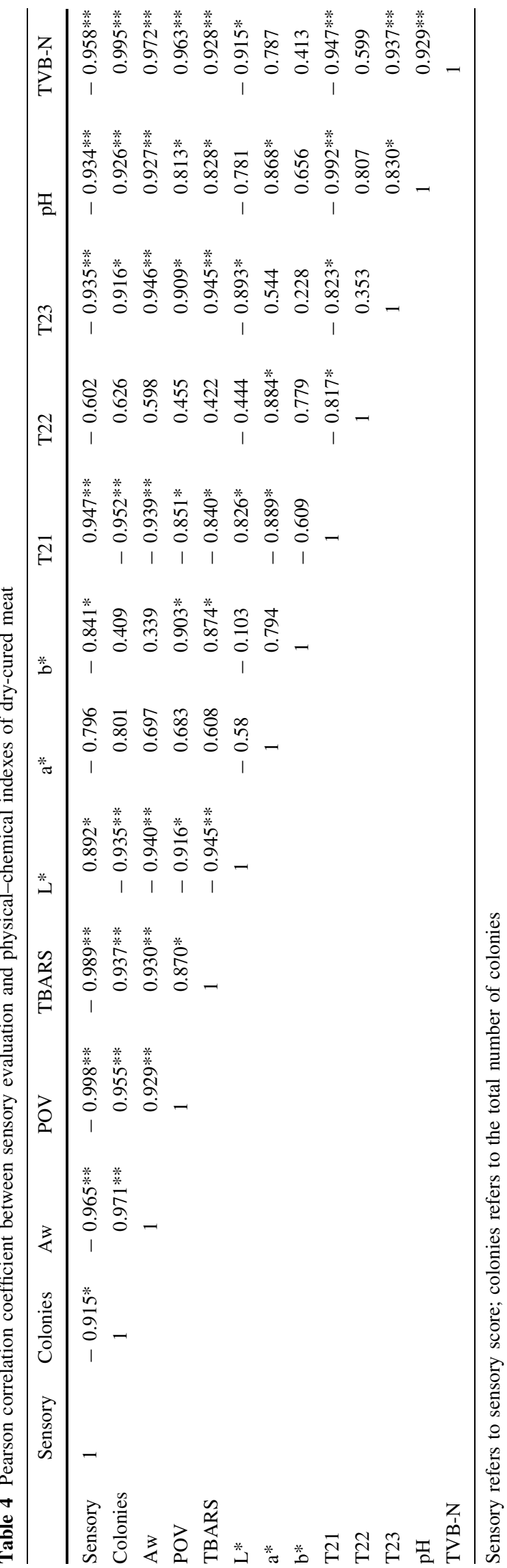

peroxidation value larger, this has a certain relationship with the number of microorganisms and the production of enzymes. Strong microbial may affect the increase of peroxide value; Fourthly, the fat of dry-cured meat has a certain volatility, and the oil has a certain loss after PL-UV irradiation.

$$
\begin{aligned}
& Q_{10}(\text { Control })=\frac{\theta s(T)}{\theta s(T+10)}=\frac{49}{25}=1.96 \\
& Q_{10}(\text { PL-UV irradiation })=\frac{\theta s(T)}{\theta s(T+10)}=\frac{70}{30}=2.33
\end{aligned}
$$

It can be predicted when the temperature is $20{ }^{\circ} \mathrm{C}$ :

$$
\begin{aligned}
& \theta_{s}(20)(\text { Control })=1.96^{\frac{47-20}{10}} \times 25=153 \mathrm{~d} \\
& \theta_{s}(20)(\text { PL-UV irradiation })=2.33^{\frac{47-20}{10}} \times 45=294 \mathrm{~d}
\end{aligned}
$$

According to the ASLT method, the predicted shelf life of the Control at $20{ }^{\circ} \mathrm{C}$ was $153 \mathrm{~d}$. The predicted shelf life of PL-UV irradiation group at $20{ }^{\circ} \mathrm{C}$ was $294 \mathrm{~d}$. In the actual storage experiment, the actual shelf life of the Controlat $20^{\circ} \mathrm{C}$ was $160 \mathrm{~d}$ and the actual shelf life of PLUV irradiation group at $20^{\circ} \mathrm{C}$ was $280 \mathrm{~d}$. The predicted value was comparable to the actual value. There was a small difference between the predicted value and the actual experimental value, but it was not significant $(P>0.05)$. Therefore, the ASLT method can be used to predict the shelf life of dry-cured meat products. The method proved that PL-UV irradiation could prolong the shelf life of drycured meat (Fig. 3).

\section{Conclusion}

A pulsed light-UV irradiation method (PL-UV) was adopted to treat Chinese traditional dry-cured meat according to the parameter. The inactivation rate reached $99.59 \%$. The inactivation rates of four groups were decreased in the following order: PL-UV irradiation $>$ PL irradiation $>$ UV irradiation $>$ Control. Moreover, the water activity was related to the inactivation rate in drycured meat processed by pulsed UV irradiation. the indexes verified the feasibility and safety of this method. With the ASLT method, the shelf life of dry-cured meat with PL-UV irradiation at $20{ }^{\circ} \mathrm{C}$ was predicted to be $294 \mathrm{~d}$. This method proved that the PL-UV irradiation technology could prolong the shelf life of dry-cured meat and improve the quality of dry-cured meat.

Acknowledgements This work is supported by the Natural Science Foundation of China (31660496), the Talents of Platform in Guizhou Province, China ([2016]5662), the Excellent Graduate Student Program Of Guizhou Province, China ([2015]6004-2), the Guizhou Graduate Special Food Processing Innovation Workstation, China (JYS[2015]009), and Project of the Innovation Fund for Graduate 
Students of Guizhou University, China, Research Engineer (201 7023).

\section{References}

Aguiló-Aguayo I, Charles F, Renard CMGC, Page D, Carlin F (2013) Pulsed light effects on surface decontamination, physical qualities and nutritional composition of tomato fruit. Postharvest Biol Technol 86:29-36

Asefa DT, Kure CF, Gjerde RO, Omer MK, Langsrud S, Nesbakken T (2010) Fungal growth pattern, sources and factors of mould contamination in a dry-cured meat production facility. Int J Food Microbiol 140:131

Bai YH, You-Jun WU, Zhang X, Guo JL, Ren W, Wang GC (2008) Study on biological safety improvement of chilled meat treated by ultra-high pressure. Sci Technol Food Ind 6:99-101

Berdagué JL, Monteil P, Montel MC, Talon R (1993) Effects of starter cultures on the formation of flavour compounds in dry sausage. Meat Sci 35:275

Bovercid S, Belletti N, Garriga M, Aymerich T (2012) Response surface methodology to investigate the effect of high pressure processing on salmonella inactivation on dry-cured ham. Food Res Int 45:1111-1117

Cai L, Cao A, Bai F, Li J (2015) Effect of $\varepsilon$-polylysine in combination with alginate coating treatment on physicochemical and microbial characteristics of Japanese sea bass (Lateolabrax japonicas) during refrigerated storage. LWT Food Sci Technol 62:1053-1059

Chen GS, Lin HC, Wu MT (2009) Intense pulsed light irradiation may reverse activator protein-1 expression induced by ultraviolet b light. J Am Acad Dermatol 61:528-529

Chen BY, Lung HM, Yang BB, Wang CY (2015) Pulsed light sterilization of packaging materials. Food Pack Shelf Life 5:1-9

Colzato M, Scramin JA, Forato LA, Colnago LA, Obg A (2011) $1 \mathrm{~h}$ nmr investigation of oil oxidation in macadamia nuts coated with zein-based films. J Food Process Preserv 35:790-796

Funes GJ, Gómez PL, Resnik SL, Alzamora SM (2013) Application of pulsed light to patulin reduction in Mcilvaine buffer and apple products. Food Control 30:405-410

Ganan M, Hierro E, Hospital XF, Barroso E, Fernández M (2013) Use of pulsed light to increase the safety of ready-to-eat cured meat products. Food Control 32:512-517

Guan M, Zhang J, Chen Y, Liu W, Kong N, Zou H (2015) Effect of uv irradiation, sample thickness and storage temperature on storability, bacterial activity and functional properties of liquid egg. J Food Sci Technol 52:4414-4422

Guizani N, Rahman MS, Al-Ruzeiqi MH, Al-Sabahi JN, Sureshchandran S (2014) Effects of brine concentration on lipid oxidation and fatty acids profile of hot smoked tuna (Thunnus albacares) stored at refrigerated temperature. J Food Sci Technol 51:577

Health and Family Planning Commission (2015) China Standard for Food Safety, cured meat products: G B2730-2015[s]. China Standard Press, Beijing, pp 1-2

Huang Y, Li H, Huang T, Li F, Sun J (2014) Lipolysis and lipid oxidation during processing of Chinese traditional smoke-cured bacon. Food Chem 14:31-39

Jerkovic I, Mastelic J, Tartaglia S (2007) A study of volatile flavour substances in dalmatian traditional smoked ham: impact of drycuring and frying. Food Chem 104:1030-1039

Kayalvizhi V, Pushpa AJS, Sangeetha G, Antony U (2016) Effect of pulsed electric field (PEF) treatment on sugarcane juice. J Food Sci Technol 53:1-9
Kim SJ, Cho AR, Han J (2013) Antioxidant and antimicrobial activities of leafy green vegetable extracts and their applications to meat product preservation. Food Control 29:112-120

Koh PC, Noranizan MA, Karim R, Nur Hanani ZA (2016) Microbiological stability and quality of pulsed light treated cantaloupe (Cucumis melo 1. reticulatus cv. Glamour) based on cut type and light fluence. J Food Sci Technol 53:1798-1810

Koutchma T (2014) Novel preservation applications of UV light. In: Preservation and shelf life extension, chap 7. Academic Press, London, pp 45-51

Koyyalamudi SR, Jeong SC, Pang G, Teal A, Biggs T (2011) Concentration of vitamin D2 in white button mushrooms (Agaricus bisporus) exposed to pulsed UV light. J Food Compos Anal 24:976-979

Lagunas-Solar MC (2014) Food technologies: pulsed ultraviolet radiation processing. Encyclo Food Safety 3:225-238

Lara JAF, Senigalia SWB, Oliveira TCRM, Dutra IS, Pinto MF, Shimokomaki M (2003) Evaluation of survival of staphylococcus aureus, and clostridium botulinum, in charqui meats. Meat Sci 65:609-613

Leygonie C, Britz TJ, Hoffman LC (2012) Meat quality comparison between fresh and frozen/thawed ostrich M. iliofibularis. Meat Sci 91:364-368

Li T, Hu W, Li J, Zhang X, Zhu J, Li X (2012) Coating effects of tea polyphenol and rosemary extract combined with chitosan on the storage quality of large yellow croaker (pseudosciaena crocea). Food Control 25:101-106

Liu L, Cao SQ, Chen W, Xiang-Yang QI, Yuan YJ (2014) Effects of pulsed light and ultraviolet-C irradiation on the activity of polyphenol oxidase from honey peach. J Nucl Agric Sci 28:85-90

Mortensen M, Thybo AK, Bertram HC, Andersen HJ, Engelsen SB (2005) Cooking effects on water distribution in potatoes using nuclear magnetic resonance relaxation. J Agric Food Chem 53:5976-5981

Pignoli G, Bou R, Rodriguezestrada MT, Decker EA (2009) Suitability of saturated aldehydes as lipid oxidation markers in washed turkey meat. Meat Sci 83:412-416

Prados MD, Garcia-Perez JV, Benedito J (2016) Ultrasonic characterization and online monitoring of pork meat dry salting process. Food Control 60:646-655

Ribeiro C, Canada J, Alvarenga B (2012) Prospects of UV radiation for application in postharvest technology. Emir J Food Agric 24:586-597

Rodtong S, Nawong S, Yongsawatdigul J (2005) Histamine accumulation and histamine-forming bacteria in indian anchovy (Stolephorus indicus). Food Microbiol 22:475-482

Ruiz-Capillas C, Tahmouzi S, Triki M, Rodríguez-Salas L, JiménezColmenero F, Herrero AM (2015) Nitrite-free asian hot dog sausages reformulated with nitrite replacers. J Food Sci Technol 52:4333-4341

Taghvaei M, Jafari SM, Nowrouzieh S, Alishah O (2015) The influence of cooking process on the microwave-assisted extraction of cottonseed oil. J Food Sci Technol 52:1138-1144

Villalobosdelgado LH, Caro I, Blanco C, Morán L, Prieto N, Bodas R (2014) Quality characteristics of a dry-cured lamb leg as affected by tumbling after dry-salting and processing time. Meat Sci 97:115

Wambura P, Verghese M (2011) Effect of pulsed ultraviolet light on quality of sliced ham. LWT Food Sci Technol 44:2173-2179

Wu X, Song X, Qiu Z, He Y (2016) Mapping of tbars distribution in frozen-thawed pork using nir hyperspectral imaging. Meat Sci 113:92

Yang Q, Sun DW, Cheng W (2017) Development of simplified models for nondestructive hyperspectral imaging monitoring of 
TVB-N contents in cured meat during drying process. J Food Eng 192:53-60

Yano Y, Kataho N, Watanabe M, Nakamura T, Asano Y (1995) Changes in the concentration of biogenic amines and application of tyramine sensor during storage of beef. Food Chem 54:155-159

Yantao WU, Cui C, Sun W, Yang B, Zhao M (2010) Effects of Staphylococcus condimenti, and micrococcus caseolyticus, on the volatile compounds of Cantonese sausage. J Food Process Eng 32:844-854
Zhang J, Zhao X (2017) Changes in protein hydrolysates during processing of Chinese traditional dry-cured bacon (laròu) production. J Food Biochem 41:2

Zhou GH, Xu XL, Liu Y (2010) Preservation technologies for fresh meat-a review. Meat Sci 86:119-128

Publisher's Note Springer Nature remains neutral with regard to jurisdictional claims in published maps and institutional affiliations. 